\title{
Inflation convergence and the determinant factors: A case study on 31 provinces in Indonesia
}

\author{
Rifdah Silfanah Mukhlish'; Diah Wahyuningsih²* \\ 1), 2) Faculty of Economics and Business, Universitas Trunojoyo Madura, Indonesia \\ *To whom correspondence should be addressed. Email: diahwahyuningsih@yahoo.com
}

\begin{abstract}
This study aims to estimate (the possibility) the inflation convergence among regionals in Indonesia and also analyze the determinant/source factor of the regional inflation. The population of this study consists of 31 provinces by using secondary data of the 20082017 period. Consumer Price Index becomes the dependent variable while Gross Regional Domestic Product, Provincial Minimum Wage, credit and Open Unemployment Level become the independent variable. This research uses panel data analysis and Fixed Effect Model regression estimation approach. The result showed that inflation convergence happened among regionals in Indonesia that can be seen through the X1 variable coefficient value of -0.635457 since the value of $\beta<0$. While for the convergence speed calculation, the measurement result showed that the duration needed by the inflation to return to the initial balance or its natural value is 68 months. The study result also showed that Gross Regional Domestic Product, Provincial Minimum Wage, credit and Open Unemployment Level have significant influence on the Indonesia's regional Inflation in 2008-2017.
\end{abstract}

Keywords: Convergence, Panel data, Regional inflation

JEL Classification: C33, O47, E31

\section{INTRODUCTION}

Inflation is a phenomenon in economy which becomes the discussion topic related to its broad impact on the macro economy aggregate. Inflation becomes the main focus of the monetary authority due to its influence on macroeconomic variables such as national output and unemployment (Utama, Wijaya, \& Lim, 2017). Bank Indonesia as the monetary authority has defined the final goal that is to achieve and maintain the stability of rupiah value on the goods and service price, which is reflected through inflation (internal stability and external stability). Maintaining inflation within the tolerable level is not only the aim of domestic price stability, but often becomes the requirement to consider by the monetary policy makers (Alagidede, Coleman, \& Adu, 2014). Especially, the rupiah stability can be reflected through the relative goods and service price stability. Therefore, since 2005 Bank Indonesia has been implementing a monetary policy framework which uses inflation as the main target of the monetary policy or known as Inflation Targeting Framework (ITF).

The Inflation Targeting Framework (ITF) implementation indicates a monetary policy change at the post-monetary crisis in Indonesia. The benefits of the policy depend on the central bank's credibility. This is because inflation expectations play a critical role in economic agent's decisions on consumption, investment, wage-setting, asset pricing, 
and so forth, through their effect on the real interest rate. Inflation targeting affects macroeconomic variables and how the credibility of inflation targeting affects the transparency of monetary policy (Kim, Kang, \& Ka, 2020). This study is significant in terms of formulating the monetary policy above since Bank Indonesia should comprehend the inflation characteristics and dynamics in the more detailed and comprehensive way.

The differences in inflation could be due to regional heterogeneities in the relative productivity growth of the tradeable versus the non-tradeable sectors (BalassaSamuelson effect) (Dridi \& Nguyen, 2019). The original Balassa-Samuelson model assumes that the economy consists of the tradable (T) and the non-tradable (NT) sectors, differing with respect to productivity growth (biased towards the tradable sector) (Konopczak \& Welfe, 2017). A region with higher inflation experiences an increased dollarization of their domestic savings and decreased dollarization of loan on domestic and company in the non-tradeable sector (Brown, Haas, \& Sokolov, 2017). However, the national data investigation is inadequate, since Indonesia has a very wide region with different economic structure. Regional data implementation concerning the inflation behavior is quite significant since national inflation is dominated only by several regions in Indonesia. Meanwhile, the understanding concerning regional inflation behavior is important to gain national inflation calculated based on the regional inflation with the value of regional CPI is $78 \%$ of national CPI. Regional inflation is also assumed as the main indicator of supply shocks. Besides, policy and efforts conducted to control the regional inflation has a strategic role which means it brings Bank Indonesia closer to its local stakeholder. Moreover, if the centered monetary policy is implemented, it could impact to the asymmetric policy among regions, since each region has its own characteristics and economy structure including the inflation.

Inflation mapping among regions showed the inflation variation among provinces in Indonesia, either in terms of level or volatility. Usually, the isolated and underdeveloped regions such as the Eastern region of Indonesia (KTI), especially East Nusa Tenggara, Papua, West Kalimantan, West Sulawesi, Central Sulawesi, and South Sulawesi tend to show a relatively higher inflation compared to the more advanced region and located in the center of economy, such as Java and Bali. It is caused by the specific local factor, especially the obstacle in distributing goods as the result of lacking infrastructure and the booming economy at the autonomy era as well as the international commodity price shocks. The high inflation dispersion among regions can also imply the labor market in Indonesia, wage level determination and living standard.

According to Ridhwan, Werdaningtyas, \& Grace (2013) the research about factor decomposition of inflation heterogeneity among regions in Indonesia, either from the common factors category, regional factors, or local factors. The decomposition result indicated the relatively nearly balance national factor (54\%) and regional/local factor $(46 \%)$ in explaining the inflation variability among regions. Spatially, the highest common factor is in Java region, while the biggest local factor is in the eastern region of Indonesia such as Maluku, North Maluku, Papua, and North Sulawesi. The dynamic data panel model estimation result showed that the regional inflation determinant factor of regional inflation in Indonesia could be explained statistically significant by the adaptive and anticipative expectation factor although it was known that the scale of the first behavior was relatively more dominant than the second behavior. In line with the theory, the other related variables, such as exchange rate, output gap, and international oil price also had significant influence on inflation. It resulted on the wage variable which also gave significant influence on inflation and the contribution was quite sizeable at $11,71 \%$. 
The relatively high inflation level variation among regions in Indonesia can be caused by various factors, especially as the result of different economy structure and characteristics of each region. The different structure can be caused by the endogenous factor which reflects the existence of a power from the endowment or support factor of the region and exogenous factor which tend to be from outside of the region. However, by conducting the geographical or spatial approach and economic approach among provinces will create a possibility of interrelation, either among provinces in a region/economy zone or among the regions/zones itself which especially caused by trade and the effect of inter-region economic competition. Various regional information can be included in a monetary union (Nagayasu, 2011).

Empirical analysis used to know the characteristics and dynamics of the inflation level of Indonesia from the regional perspective are as follows: first, classifying the sources which differs the regional inflation. Second, by focusing on the local factors which drive the regional inflation gap, the next step is analyzing determinant factors of the inflation difference in the whole region of Indonesia. The regional inflation level may increase the knowledge of the monetary policy makers concerning the inflation dynamics in a broad way (Beck, Hubrich, \& Marcellino, 2006). Persistent heterogeneity in the inflation expectation (with dependent rational expectation prevalence) exists due to the result of long term equilibrium (Silveira \& Lima, 2014). Convergence can be defined as a tendency of movement of one or more variables towards a certainly same point. To achieve economy integration, convergence criteria becomes one of requirements in creating a single currency, either the nominal convergence (inflation and interest rate) or the real convergence (income per capita, labor productivity, and comparative price rate). Inflation convergence among all European Union member states in recent years implies that inflation rates across the EU do not permanently deviate from the European Central Bank's goal for price stability. Consequently, inflation synchronization does not seem to pose a challenge for further enlargement of the euro area (Brož \& Kočenda, 2018). The theory of price convergence is commonly related to the Law of One Price (LOOP) theory and market integration. The LOOP theory stated that an efficient market shall have the same price if it is stated with the same currency since merchants demand the prevailing higher price and the buyers demand the market lowest price. In the perfectly integrated market, if a price in a certain location increased drastically than those in other locations, then the market power will tend to drive the price to move back into the equality. The LOOP theory is only possible for the non goods.

This study aims to analyze how far the inflation level could be varied in the whole regions and what factors which could make the difference. However, 3 provinces were removed, they are North Kalimantan, Papua, and West Papua because North Kalimantan is a relatively new province while Papua and West Papua were removed because of the obstacle in obtaining the data. Therefore, only 31 provinces are used.

\section{METHODS}

\section{Data type and source}

This study used panel data which is the combination of the cross section and time series data. The cross section data is obtained from 31 provinces in Indonesia while the time series data is obtained from the 2008-2017 period. The data type is secondary and is obtained from Badan Pusat Statistik (BPS) and Bank Indonesia. This study required data concerning inflation level by using Consumer Price Index (CPI) proxy, exchange value, Gross Regional Domestic Product (GDP), international oil price, credit and provincial minimum wage (UMP) and Open Unemployment Level (TPT) 


\section{Econometrics and model specification}

\section{Inflation convergence model}

The method used to estimate convergence is the fixed effect model data panel method. This method will be quite relevant to explain the individual (regional) inflation convergence compared to the national level.

\section{Speed of convergence}

After conducting convergence test, the next step is measuring the speed on the convergence itself (speed of convergence). Cecchetti \& Li, (2008) said that speed of convergence is the duration needed by inflation to return to the initial balance or natural value after the shock which can be measured by using half-life deviation equation.

$$
\theta=\frac{\ln (0.5)}{\ln (1+\beta)}
$$

\section{Panel data regression}

This study used panel data analysis where the panel data itself is the combination of time series and cross section data. Panel data or longitudinal is following the sample from time to time and providing several observations on each individual in the sample. Panel data is available broadly at the advanced and developing country (Hsiao, 2003). The equation of panel data which is the combination of time series and cross section data can be written as in the following:

$$
\begin{aligned}
& Y_{\text {it }} \quad=\beta_{0}+\beta_{1} X_{\text {it }}+\varepsilon_{\text {it }} \ldots \ldots . . \\
& \mathrm{i}=1,2, \ldots, \mathrm{N} ; \mathrm{t}=1,2, \ldots, \mathrm{N}
\end{aligned}
$$

In the model, $\mathrm{Y}$ is the dependent variable while $\mathrm{X}$ is the independent variable. $\mathrm{N}$ shows the amount of observation while $\mathrm{T}$ shows the amount of analyzed time.

There are three techniques of panel data regression model estimation that can be used namely pooled least square (PLS), fixed effect (FEM) model and random effect model (REM). There are two tests conducted to determine the most suitable technique used in estimating the panel data regression. Chow Test is used to choose between the PLS or FEM method. A Hausman test examines differences in the estimated parameters and the result is used to determine whether the REM and FEM estimates are significantly different. The null hypothesis of the Hausman test is that if the assumptions of the REM hold, then the REM produces the same estimated parameters as the FEM but they are better. If REM assumption do not hold, then the estimated parameters are significantly different and the REM estimates contain bias. If you fail to reject the null hypothesis in a Hausman test, you use the REM estimates. If reject the null hypothesis in a Hausman test, using the FEM estimates as the alternative hypothesis implies that the FEM estimates are consistent (Pedace, 2013).

\section{Estimation technique}

This study will discuss the inflation convergence happens among provinces in Indonesia and the determinant factors influenced the regional inflation. The models used in this study are as follows:

\section{a. Convergence model}

Following Cecchetti \& $\mathrm{Li}(2008)$ here is the estimation equation used:

$$
\Delta \rho_{\text {Rel it }}=\alpha_{1}+\beta \rho_{\text {Rel it }-1}+\sum_{h=1}^{k} \gamma_{h} \Delta \rho_{\text {Rel it }-h}+\varepsilon_{i t}
$$

\section{Where:}

$$
\mathrm{P}_{\text {Rel it }}=\ln \left(\mathrm{p}_{\text {it }} / \bar{p}_{\text {it }}\right)=\text { price differences }
$$




$$
\begin{array}{ll}
\mathrm{p} & =\text { price index in province } \\
\mathrm{p}_{\mathrm{it}} & =\text { national price index } \\
\mathrm{k} & =\text { maximum number of lags }
\end{array}
$$

The convergence test is obtained based on the estimation value of $\beta$ (speed of convergence) that is when the value of $\beta>0$ showed the most divergent price and if the value of $\beta<0$ showed the convergent price. The estimation result with the smallest Schwarz Bayesian

\section{b. Panel data regression}

Panel data regression is used to analyze the determinant factor of the regional inflation in Indonesia which is applied in the following model:

$$
\begin{aligned}
& \mathrm{IHK}_{\text {it }}=\beta_{0}+\beta_{1} \mathrm{GRDP}_{i t}+\beta_{2} \mathrm{UMP}_{\mathrm{it}}+\beta_{3} \mathrm{CREDIT}_{\mathrm{it}}+\beta_{4} \mathrm{TPT}_{\mathrm{it}}+\varepsilon_{\mathrm{it}} \\
& \text { Where: } \\
& \mathrm{IHK}_{\mathrm{it}} \quad \text { : Consumer Price Index in province } \mathrm{i} \text { in year } \mathrm{t} \\
& \text { GRDP }_{\text {it }} \quad \text { : Gross Regional Domestic Product in province } \mathrm{i} \text { in year } \mathrm{t} \\
& \mathrm{UMP}_{\text {it }} \quad \text { : Provincial Minimum Wage in province } \mathrm{i} \text { in year } \mathrm{t} \\
& \text { CREDIT }_{\text {it }} \text { : Credit in province } \mathrm{i} \text { in year } \mathrm{t} \\
& \mathrm{TPT}_{\text {it }} \quad \text { : Open Unemployment Rate in province } \mathrm{i} \text { in year } \mathrm{t} \\
& \varepsilon \quad \text { : error term }
\end{aligned}
$$

\section{RESULT AND DISCUSSION}

\section{The estimation result of inter-regional inflation convergence model}

Convergence test was conducted on each province by using the inflation data of 31 provinces in Indonesia. The estimation result with the smallest Schwarz Bayesian Criterion (SBC) will be chosen as the best model.

Table 1. Convergence results in the FEM test

\begin{tabular}{ccc}
\hline Variable & Coefficient & Probability \\
\hline C & 0.637656 & 0.0000 \\
X1(-1) & -0.635457 & 0.0000 \\
X2(-4) & -0.087006 & 0.3344 \\
\hline
\end{tabular}

The test result showed the inflation convergence among provinces in Indonesia which can be seen from the X1 variable coefficient value of -0.635457 since the value of $\beta<0$. After conducting convergence test, the next step is measuring the speed of convergence. Cecchetti \& $\mathrm{Li}$ (2008) said that speed of convergence is the duration needed by inflation to return to the initial balance or natural value after the shock which can be measured by using half-life deviation equation. Regional inflation which moved in convergence to national inflation showed that shock in each region tend to be temporary that it will not cause persistent change to the national inflation.

Table 2. Convergence speed calculation results

\begin{tabular}{cccc}
\hline Variable & Coefficient & Probability & Half time \\
\hline C & 0.637656 & 0.0000 & - \\
X1(-1) & -0.635457 & 0.0000 & 68.68 \\
\hline
\end{tabular}

The measurement result showed that the duration needed by the inflation to return to the initial balance or natural value is 68 months. Regional inflation takes 68 months to move convergently towards national inflation, this shows that the shock that occurred in each region tends to be temporary, causing persistent changes to national inflation. Evaluate differences in regional inflation persistence especially if it can cause differences 
in regional real interest rates and be a concern by the monetary authority. Differences in inflation persistence between regions remain and pose a challenge for this country. In general, regional inflation outside Java tends to be higher than in Java with a greater level of volatility.

Decomposition using the factor analysis method indicates that the role of national and regional factors in explaining the variability of domestic inflation is equally important. Common factors are mainly in the Java region, while local factors are in Eastern Indonesia. Half life statistical convergence of prices relative to the national average requires 29 months for 16 provinces (Ridhwan, Werdaningtyas, \& Grace, 2013).

The convergence of price indexes in the US. The purpose of his research is to determine the factors that influence the speed of convergence. The methodology used is half time during the period 1918-1995. Half price convergence in the US is 9 years and can be explained by transportation costs and the amount of shocks (Cecchetti, Mark, \& Sonora, 2002). The evidence of regional inflation as statistically different among regions in Japan. The research identified the common factor driven by monetary and economic activities, and then found that inflation responds to the common shock differently among regions. Finally, no evidence of price convergence is obtained in our group consisting of all regions although there seems to be convergence among subgroups. Discrepancies in regional income seem to go some way toward explaining those in regional inflation (Nagayasu, 2011).

Inflation convergence in Indonesia is a monetary phenomenon where demand pull is more dominant, a number of literatures have emphasized the large role of the supply side to regional inflation. This non-monetary factor is triggered by cost pressures on goods and services as a result of problems in the availability, adequacy and affordability of inventories. Supply-side inflation has been a problem in controlling regional inflation in Indonesia lately. As part of the initiative to monitor and control inflation in the regions, particularly inflation caused by cost suppression factors.

\section{The estimation result of determinant/inflation source}

There are three models used in this study to analyze the panel data regression, they are PLS, FEM and REM. Then, Chow test and Hausman test were conducted to choose the most suitable model. Consumer Price Index (CPI) became the dependent variable in this study. In the other hand, there were four independents variables namely Gross Regional Domestic Product (GRDP), Provincial Minimum Wage (UMP), credit and Open Unemployment Level (TPT).

There were three panel data regression estimations namely PLS, FEM and REM which will be compared to obtain the best model through several test such as Chow test and Hausman Test.

\section{Chow test}

Chow test was used to compare between PLS and FEM. The result of Chow test was as in the Table 3 .

Table 3. Chow test estimation results

\begin{tabular}{cccc}
\hline Effects Test & Statistic & d.f. & Probability \\
\hline Cross-section F & 4.081093 & $(30,275)$ & 0.0000 \\
Cross-section Chi-square & 114.158969 & 30 & 0.0000 \\
\hline
\end{tabular}

From the Chow test result, the chi square cross section probability value was 0.0000 less than 0.05 which means the chosen model to use was the FEM. 


\section{Hausman test}

The result of Hausman test could be seen in the Table 4 .

Table 4. Hausman Test Estimation results

\begin{tabular}{cccc}
\hline Test Summary & Chi-Sq. Statistic & Chi-Sq. d.f. & Prob \\
\hline Cross-section random & 84.655212 & 4 & 0.0000 \\
\hline
\end{tabular}

From the Chow result, the random cross section probability value was 0.0000 less than 0.05 which means the chosen model to use was the FEM.

After being tested through Chow test and Hausman test, it could be concluded that the chosen model to use was the FEM which could be seen in the Table 5.

Table 5. Fixed Effect Model estimation results

\begin{tabular}{cccc}
\hline Variable & Coefficient & Std. Error & Probability \\
\hline C & 132.07 & 30.5877 & 0.0000 \\
LOG(GRDP) & 10.4131 & 1.48764 & 0.0000 \\
LOG(UMP) & 20.0932 & 3.42965 & 0.0000 \\
LOG(CREDIT) & 6.08897 & 2.75231 & 0.0278 \\
LOG(TPT) & -11.49 & 3.58009 & 0.0015 \\
\hline
\end{tabular}

Based on the FEM regression result, statistically, it showed that the GRDP variable coefficient had positive and significant influence on regional inflation. The coefficient value of 10.41311 was defined as positive relation. It means that if the GRDP increases by $1 \%$, then the regional inflation in Indonesia will increase by $10.41 \%$. Provincial Minimum Wage (UMP) has positive and significant influence on regional inflation. The UMP coefficient value was 20.09, which means every increase on Provincial Minimum Wage (UMP) by $1 \%$ will increase $20.09 \%$ regional inflation in Indonesia. The estimation result was suitable with the theory, where Provincial Minimum Wage had a significant influence on regional inflation. The aim of minimum wage establishment is increasing the labor wage which is still below the minimum wage and also protecting the labor from those businessmen who gave inadequate wage to the labors. One of the components in establishing minimum wage is the inflation rate in each province. On one side, inflation can be caused by the lack of production and increased society's demand on a certain good. Meanwhile, in the other hand, inflation can also be caused by the increased production cost in a company which will cause the increasing production result cost. The high inflation rate will surely drive the labor to demand the increase on the provincial minimum wage. This condition may cause any significant obstacles on the economic development faced by the developing country. The problem is the decreased job vacancy as the result of increased provincial minimum wage as one of the company's production cost components. These results are consistent with research conducted by Ridhwan, Werdaningtyas, \& Grace (2013) that the provincial minimum wage has a positive and significant effect on the formation of regional inflation. Provincial minimum wage is one of the costs of production inputs in 2008-2013 which increased by an average of $20 \%$.

Credit had positive and significant influence on the regional inflation. The coefficient value of credit was 6.088973 , which means any increase on credit by $1 \%$ will increase $6.08 \%$ regional inflation in Indonesia. The estimation result is suitable to the theory where credit had positive influence on regional inflation. The correlation of inflation and credit can be seen from the amount of credit distribution. Inflation influences through nominal interest rate. It was because the real interest rate formed from the nominal interest rate was reduced by the inflation. If the inflation rate is high, then the real interest rate will decrease, this will cause the increasing amount of credit distribution caused by the decreased real interest rate. The effect of inflation change on the credit 
distribution did not happen directly but through the real interest rate at first. The high inflation is usually related to overheat economic condition. It means, the economic condition experiences overloaded demand on their products that the price will tend to increase. The over inflation will also decrease the purchasing power of money. Besides, high inflation can also decrease the real income rate obtained by the society. On the contrary, if the inflation decreased, then it will be a positive sign for the society along with the decreased risk of purchasing power of money and the risk of decreased real income.

The open unemployment level had negative significant influence on the regional inflation. The coefficient value of open unemployment level is -11.490021 , which means any increase on the open unemployment level by $1 \%$ will decrease $11.49 \%$ regional inflation in Indonesia. The estimation result is suitable with the theory where the open unemployment level had a negative influence on regional inflation. In the short term, the increasing inflation showed the economic growth, still, in the long term, high inflation will cause bad impact. The high inflation will cause the domestic goods price become relatively more expensive than the import goods. The more expensive price causes the decreased competitiveness of the domestic goods in the international market. This will impact the export value which will tend to decrease while otherwise, the import value will tend to increase.

The lack of domestic goods and service price competitiveness caused the low demand on domestic product. The production will be decreased. Some business people will decrease the production. The decreased production will cause a certain amount of labor lose their job. Economists stated their opinion that the over inflation indicates the worse economic condition of a country. The high inflation may drive the central bank to increase the interest rate. This caused contraction or negative growth in the real sector. The further impact is the increasing unemployment. Thus, inflation and unemployment were the two parameters which can be used to measure the quality of the economic health faced by a country.

\section{CONCLUSION AND RECOMMENDATIONS}

\section{Conclusion}

Speed of convergence 68 months that indicates the length of time needed by inflation to return to its initial balance or natural value. By using panel data regression analysis with the FEM as the best model, the result concluded that the determining factors of the regional inflation or determinant/source of inflation among regions are: Gross Domestic Regional Product (GRDP) which had positive and significant influence on the regional inflation in Indonesia during 2008-2017. The Provincial Minimum Wage (UMP) had positive and significant influence on the regional inflation in Indonesia during 20082017. Credit had positive and significant influence on regional inflation in Indonesia during 2008-2017. Open unemployment level (TPT) had negative significant influence on the regional inflation in Indonesia during 2008-2017.

\section{Recommendation}

Considering the expectation factor which is relatively dominant in terms of influencing the domestic inflation rate, especially at the regional level, the coordination between policy makers - in this case are the government and Bank Indonesia - either in the central or regional level shall be enhanced that the role of KPw-BI (Representative Office of Bank Indonesia) in the regional level will be more significant in directing the economic agents expectation in their working area. One of the concrete steps taken is 
through the Regional Inflation Controlling Team (TPID) and/or other related forums at the regional level which will be more relevant to be developed to reinforce the strategic alliance to develop the regional economy.

The effort of controlling inflation in the region or province shall be focused on the efforts to guarantee the price affordability. Besides, the government shall reinforce the activity of providing clear information to the society concerning various steps and policies which will be taken by the government in controlling the price. It was conducted to maintain the society's expectation on the necessity price.

\section{ACKNOWLEDGMENT}

We grateful to Bank Indonesia Institute for research assistance funds through the Bank Indonesia Institute research assistance program.

\section{REFERENCES}

Alagidede, P., Coleman, S., \& Adu, G. (2014). A Regional Analysis of Inflation Dynamics in Ghana: Persistence, Causes and Policy Implications. Working Paper, (October). Retrieved from https://www.theigc.org/wpcontent/uploads/2014/09/Alagidede-Et-Al-2014-Working-Paper.pdf

Beck, G., Hubrich, K., \& Marcellino, M. (2006). Regional Inflation Dynamics Within And Across Euro Area Countries And A Comparison With The US. Working Paper Series, (681). Retrieved from https://www.ecb.europa.eu/pub/pdf/scpwps/ecbwp681.pdf

Brown, M., Haas, R. De, \& Sokolov, V. (2017). Regional Inflation , Banking Integration, and Dollarization. Review of Finance, (March), 1-36. https://doi.org/10.1093/rof/rfx021

Brož, V., \& Kočenda, E. (2018). Dynamics and Factors of Inflation Convergence in the European Union. Journal of International Money and Finance. https://doi.org/10.1016/j.jimonfin.2018.04.002

Cecchetti, S., \& Li, L. (2008). Do Capital Adequacy Requirements Matter for Monetary Policy? Economic Inquiry, 46(4), 643-659. https://doi.org/10.1111/j.14657295.2007.00085.x

Cecchetti , S., Mark, N., Sonora, R. (2002). Price Index Convergence Amomg US Cities. International Economic Review, 43(4), 1081-1099. https://doi.org/10.1111/14682354.t01-1-00049

Dridi, J., \& Nguyen, A. D. M. (2019). Assessing Inflation Convergence In The East African Community. Journal of International Development, 31(2), 119-136. https://doi.org/https://doi.org/10.1002/jid.3396

Hsiao, C. (2003). Analysis of Panel Data. Retrieved from https://assets.cambridge.org/052181/8559/sample/0521818559ws.pdf\%0D

Kim, Y., Kang, K., \& Ka, K. (2020). Do Bond Markets Find Inflation Targets Credible? Evidence from Five Inflation-Targeting Countries. International Review of Economics and Finance, 67(1), 66-84. https://doi.org/10.1016/j.iref.2019.12.007

Konopczak, K., \& Welfe, A. (2017). Convergence-Driven Inflation and the Channels of its Absorption. Journal of Policy Modeling, 1-16. https://doi.org/10.1016/j.jpolmod.2017.02.001

Nagayasu, J. (2011). Heterogeneity and Convergence of Regional Inflation (Prices). Journal of Macroeconomics, 33(4), 711-723. 
https://doi.org/10.1016/j.jmacro.2011.07.002

Pedace, R. (2013). Econometrics for Dummies. Retrieved from https://books.google.com/ Ridhwan, M., Werdaningtyas, H., \& Grace, M. (2013). Dinamika Dan Heterogenitas Inflasi Regional di Indonesia. Working Paper, 11. Retrieved from https://www.bi.go.id/id/publikasi/wp/Documents/Dinamika dan Heterogenitas Inflasi Regional di Indonesia.pdf

Silveira, J., \& Lima, G. (2014). Heterogeneity in Inflation Expectations and Macroeconomic Stability under Satisficing Learning. Working Paper Series, (28), $1-25$. Retrieved from

https://econpapers.repec.org/scripts/redir.pf?u=http\%3A\%2F\%2Fwww.repec.eae.f ea.usp.br\%2Fdocumentos\%2FSilveira_Lima_28WP.pdf;h=repec:spa:wpaper:2014 wpecon 28

Utama, C., Wijaya, M., \& Lim, C. (2017). The Role of Interest Rates and Provincial Monetary Aggregate in Maintaining Inflation in Indonesia. Buletin Ekonomi Moneter Dan Perbankan, 19(3), 267-286. https://doi.org/10.21098/bemp.v19i3.666

(C) 2020 by the authors. Licensee JPPD, Indonesia. This article is an open access article distributed under the terms and conditions of the Creative Commons Attribution (CC BY) license (http://creativecommons.org/licenses/by/4.0/). 